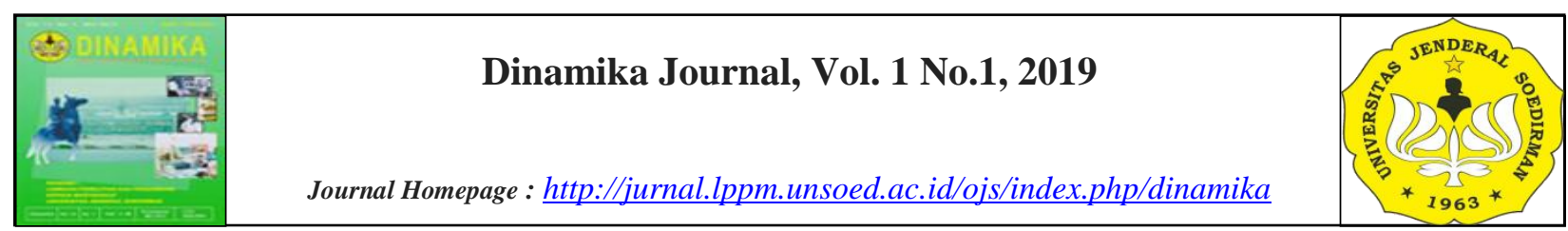

\title{
PENINGKATAN KUALITAS ABON IKAN LELE DENGAN PERBAIKAN PROSES PRODUKSI DAN KEMASAN DI UKM ABON JAGO PURWOKERTO DAN PRIMA MELATI PURBALINGGA
}

\author{
Sri Marnani ${ }^{1}$, Petrus Hary Tjahja Soedibya ${ }^{1}$, Arif Mahdiana ${ }^{1}$ dan Taufik Budhi Pramono ${ }^{1}$ * \\ ${ }^{1}$ Fakultas Perikanan dan Ilmu Kelautan Universitas Jenderal Soedirman \\ J1. Dr. Suparno Karangwangkal Purwokerto 53123, Banyumas, Jawa Tengah \\ *Coressponding author : tblpram@yahoo.com
}

Received 2 May 2019; Accepted 28 June 2019; Available online 30 June 2019

\begin{abstract}
Abstrak
Konsumsi ikan masyarakat perlu ditingkatkan dan salah satu caranya adalah dengan membuat produk olahan ikan seperti abon ikan. Abon ikan yang diproduksi dan dipasarkan harus higienis, sehat dan dikemas dengan baik. Tujuan dari kegiatan pengabdian kepada masyarakat adalah untuk meningkatkan pengetahuan dan keterampilan UKM dalam memproduksi olahan ikan yang sehat, tanpa limbah dan kemasan produk. Metode yang digunakan untuk transfer iptek yaitu pendampingan teknis dan belajar sambil bekerjadi dalam manajemen usaha. Penerapan ipteks yang dilakukan yaitu pelatihan pembuatan abon ikan yang sehat dan tanpa limbah, pembuatan desain kemasan dan analisa kandungan nutrisi produk. Mitra UKM telah mampu dan terampil dalam pembuatan abon yang sehat dan diversifikasi produk kerupuk ikan dari tulang/duri serta kulit. Selain itu mitra UKM juga telah terampil membuat desain dan melakukan pengemasan yang baik.
\end{abstract}

Kata Kunci : Abon, packaging, brand, UKM

\begin{abstract}
Fish consumption by citizens should be improved and one way is by making the processed products fish-like shredded fish. shredded fish product should be hygienic, healthy and well packed. The purpose of devotion activities to increase medium and micro business skill related to production of health and hygiene processed fish, zero waste and packaging. The methods this work using technical assistance and learning by doing in business management. This science-technology application is training to produce healthy shredded fish but zerowaste, packaging design and nutrition analysis of the products. The output of this work is medium and micro business partner will be capable to make healthy shredded fish, diversify fish products using the waste such as fish spines and the scale/skin. In addition, the medium and micro business partner will be capable to make good design and packaging.
\end{abstract}

Keywords: catfish shredded, packaging, brand, SMEs 


\section{PENDAHULUAN}

Ikan lele merupakan salah satu sumber protein hewani yang cukup dikenal masyarakat dan mudah diperoleh. Namun tidak jarang banyak pula masyarakat yang tidak menyukainya dengan berbagai alasan. Salah satu upaya yang dilakukan adalah dengan membuat variasi olahan ikan lele menjadi abon ikan. Produk olahan ikan lele menjadi abon merupakan upaya diversifikasi dan meningkatkan nilai tambah ikan (Yulianan dan Farida, 2010). Pengembangan olahan ikan tentunya akan mendorong pula kegiatan industri perikanan modern di semua lapisan masyarakat.

Usaha kecil menengah (UKM) Abon ikan "Jago" dan "Prima Melati" merupakan contoh industri perikanan yang telah melakukan upaya produksi olahan ikan lele menjadi abon ikan. Produknya laku di pasaran domestik atau sekitar Eks Karesidenan Bralingmascakeb (Purbalingga, Banyumas, Cilacap dan Kebumen). Usaha yang dilakukan UKM mitra tersebut benar-benar memberikan manfaat dalam penambahan pendapatan keluarga.

Kondisi kemasan dan teknik pengemasan yang dilakukan oleh oleh UKM Abon Jago dan Prima Melati masih kurang menarik desainnya dan menggunakan alat press manual untuk menutup kemasan. Kemasan yang telah jadi masih rawan terbuka, dan akan mempengaruhi kualitas produk dan penilaian konsumen terhadap keamanan pangannya. Desain kemasan dan teknik pengemasan UKM mitra perlu diperbaiki dengan alih teknologi dan peningkatan keterampilannya. Desain kemasan yang menarik diharapkan dapat meningkatkan ketertarikan konsumen dan citra produk yang baik. Teknik pengemasan dengan menggunakan continuous sealer adalah suatu teknik pengemasan menggunakan mesin yang digerakan motor listrik dan dilengkapi meja conveyor untuk menyiapkan produk yang akan dikemas serta pencetak masa kadaluasa produk. Penggunaan continuous sealer dalam kegiatan ini diharapkan UKM dapat melakukan pekerjaan pengemasan produk dengan lebih cepat, menutup kemasan sangat rapat dan berkelanjutan serta efektif dalam waktu.

Mitra UKM juga memerlukan pengetahuan dan keterampilan tentang produk olahan yang sehat yaitu pengolahan tanpa menggunakan bahan pengawet berbahaya dan MSG, tanpa limbah, produk yang memenuhi Standar Industri Indonesia (SII). Kegiatan tersebut diharapkan menjadi nilai tambah produk dan upaya pengembangan produk.

Tujuan dari kegiatan pengabdian kepada masyarakat ini yaitu meningkatkan pengetahuan dan keterampilan UKM dalam memproduksi olahan ikan yang sehat, tanpa limbah dan desain kemasan produk yang menarik serta teknik pengemasan yang baik. Harapan dari kegiatan ini, produk UKM mitra memiliki tampilan kemasan produk yang menarik serta jaminan keamanan pangan.

\section{METODE PELAKSANAAN}

Pelaksanaan kegiatan dilakukan dengan metode technical assistance (pendampingan teknis) dan learning by doing (belajar sambil bekerja) baik dalam penerapan dan pengembangan ipteks maupun manajemen usaha. Inti kegiatan yaitu memberikan bimbingan teknis, pelatihan dan pembinaan serta pendampingan bagi UKM pengolahan ikan. Transfer ipteks yang dilakukan meliputi :

1. Pelatihan dan praktek pembuatan abon serta kerupuk ikan lele dari duri dang tulang yang renyah dengan berbagaikomposisi bahan tanpa menggunakan bahan pengawet dan MSG.

2. Pelatihan pembuatan kemasan dengan menggunakan kemasan plastik tebal serta menggunakan mesin continous sealer.

3. Pelatihan desain pengemasan yang meliputi desain kemasan dan komponen-komponen yang harus ada dalam desain suatu produk yang menarik, baik dari sisi estetika, 
ergononomik, fungsional dan marketable. Mitra diperkenalkan dengan berbagai macam desain produk dan juga ditunjukkan contoh-contoh desain kemasan kerupuk ikan lele dan abon ikan lele yang sudah ada di pasar.

4. Analisis laboratorium kandungan nutrisi produk pangan. Informasi analisis laboratorium tentang kandungan nutrisi produk UKM diharapkan dapat memberikan nilai tambah produk dan menambah kepercayaan konsumen.

\section{HASIL DAN PEMBAHASAN}

\subsection{Pelatihan pembuatan olahan ikan tanpa pengawet dan MSG}

Pelatihan difokuskan dalam membuat olahan ikan yang sehat tanpa bahan pengawet dan penambaha rasa Monosodium Glutamat (MSG). Pelatihan telah dilakukan masingmasing sebanyak dua kali di tempat usaha mitra. Peningkatan pengetahuan dan keterampilan ditunjukkan dengan pemahaman tentang bahaya penggunaan bahan pengawet pada makanan dan kemampuan mengolah makanan berbahan baku dasar ikan yang sehat menggunakan bumbu-bumbu alami. Penggunaan bahan Mitra juga telah memahami bahwa penambahan penguat rasa dari bahan sintetis seperti MSG akan menimbulkan beberapa efek samping baik langsung maupun tidak langsung misalnya gatal-gatal, pusing, mual dan dapat memicu penyakit kanker. Tentunya respon tubuh terhadap bahan MSG untuk setiap orang berbedabeda.

Penggunaan bahan penambah rasa MSG dalam makanan mungkin tidak dapat dihindari, namun apabila digunakan secara terus menerus dan berlebihan dikhawatirkan dapat berakibat buruk bagi yang mengkonsumsinya. Kusumayanti et.al. (2011) menegaskan bahwa para pengolah abon ikan juga harus membuat produk yang sehat untuk dikonsumsi dan memiliki daya simpan yang baik. Hal ini juga merupakan sebagai sebuah tanggung jawab kepada konsumen.

Mitra juga telah mampu membuat variasi olahan lain seperti membuat kerupuk ikan yang berasal dari limbah tulang atau duri, kulit dan kepala serta jeroan ikan untuk pakan ikan lele peliharaan.Hal ini dapat dikatakan bahwa dalam produksi abon lele tidak ada yang terbuang sia-sia, semua dapat dimanfaatkan. Haryati dan Munandar (2012) menyatakan bahwa dengan penerapan system zero waste menjadi solusi pencemaran akibat limbah produk dan menjadi produk baru yang memiliki nilai tambah dan nilai jual.

\subsection{Pelatihan pembuatan kemasan}

Pelatihan pembuatan kemasan dilakukan langsung melihat beberapa bentuk atau jenis kemasan seperti alumunium foil, composit can, plastik kemasan di rumah kemasan Kesanku Universitas Jenderal Soedirman. Kedua mitra juga langsung memilih bentuk kemasan yang tepat untuk produknya. Mengingat produk yang telah dikenal dan laku di pasaran dengan berbagai ukuran kemasan dari plastik. Kedua mitra memilih menggunakan plastik dengan kombinasi alumunium foil. Untuk menjaga kualitas kemasan dan produknya, pengemasan dilakukan dengan menggunakan mesin Continous Sealer.

Sebelum kegiatan ini dilakukan, kemasan produk yang digunakan oleh mitra masih menggunakan plastik biasa. Hal tersebut tentunya akan mengurangi daya tarik konsumen dan kualitas produk. Pada kesempatan pelatihan ini, UKM mitra dipersilahkan memilih plastik kemasan untuk memperbaiki produknya. Kegiatan pelatihan pembuatan kemasan dapat dilihat pada Gambar 1. 


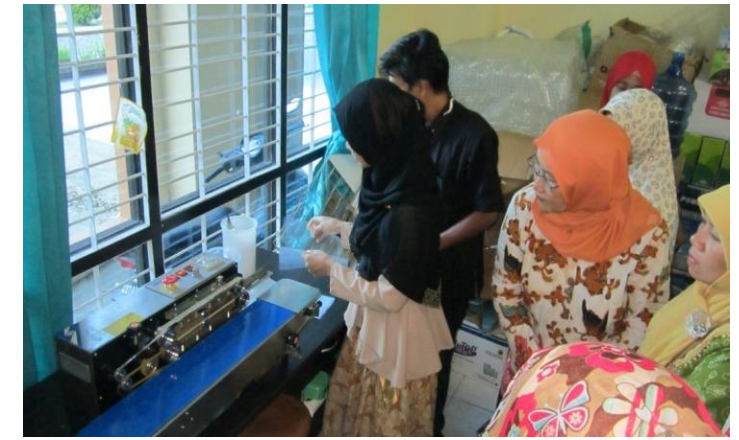

Praktek Penggunaan Continous Sealer

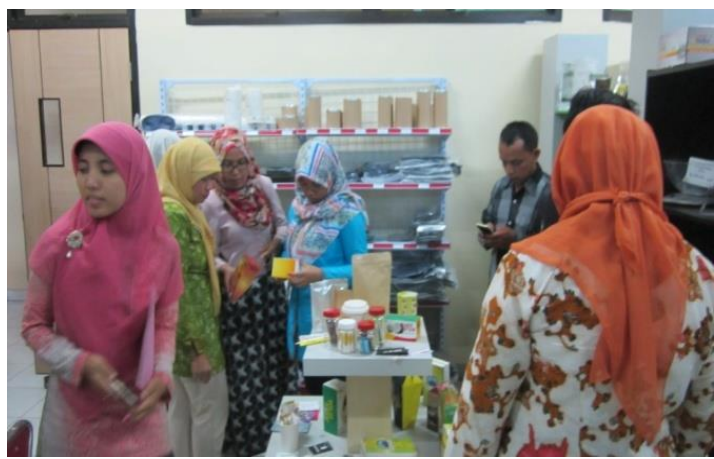

Mitra memilih kemasan di Kesanku

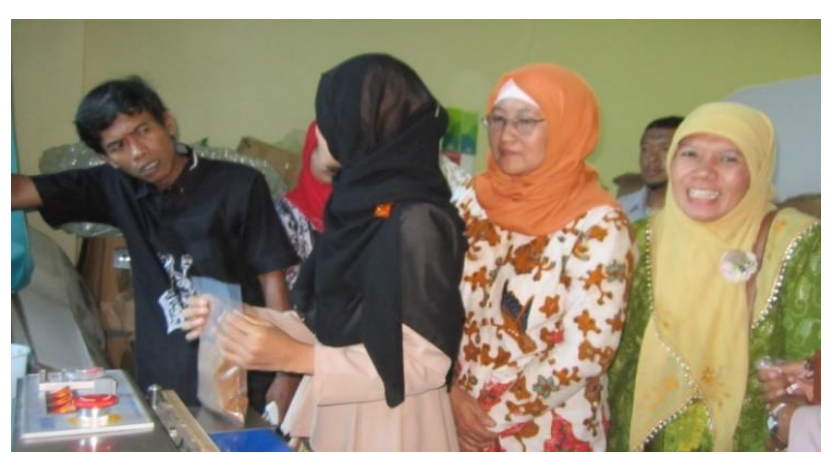

Praktek Penggunaan Continous Sealer

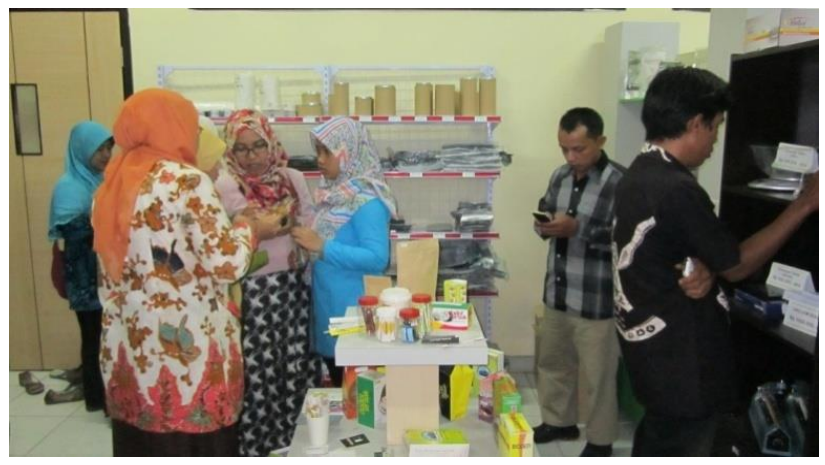

Mitra memilih kemasan di Kesanku

Gambar 1. Kegiatan pelatihan pembuatan kemasan di rumah kemasan Kesanku

\subsection{Pelatihan Desain Kemasan}

Pelatihan desain pengemasan yang diberikan meliputi desain kemasan dan komponenkomponen yang harus ada dalam desain suatu produk. Sebelum transfer teknologi dilakukan, desain kemasan mitra masih menggunakan sablon biasa dan mudah luntur. Dalam pelatihan desain kemasan ini UKM mitra diajari cara membuat desain kemasan yang menarik dan membantu UKM mitra dalam membuat desain produk yang memiliki ciri khas atau branding. Pelatihan telah dilakukan dua kali di masing-masing UKM mitra. Hasil pelatihan desain kemasan dapat dilihat pada Gambar 2.
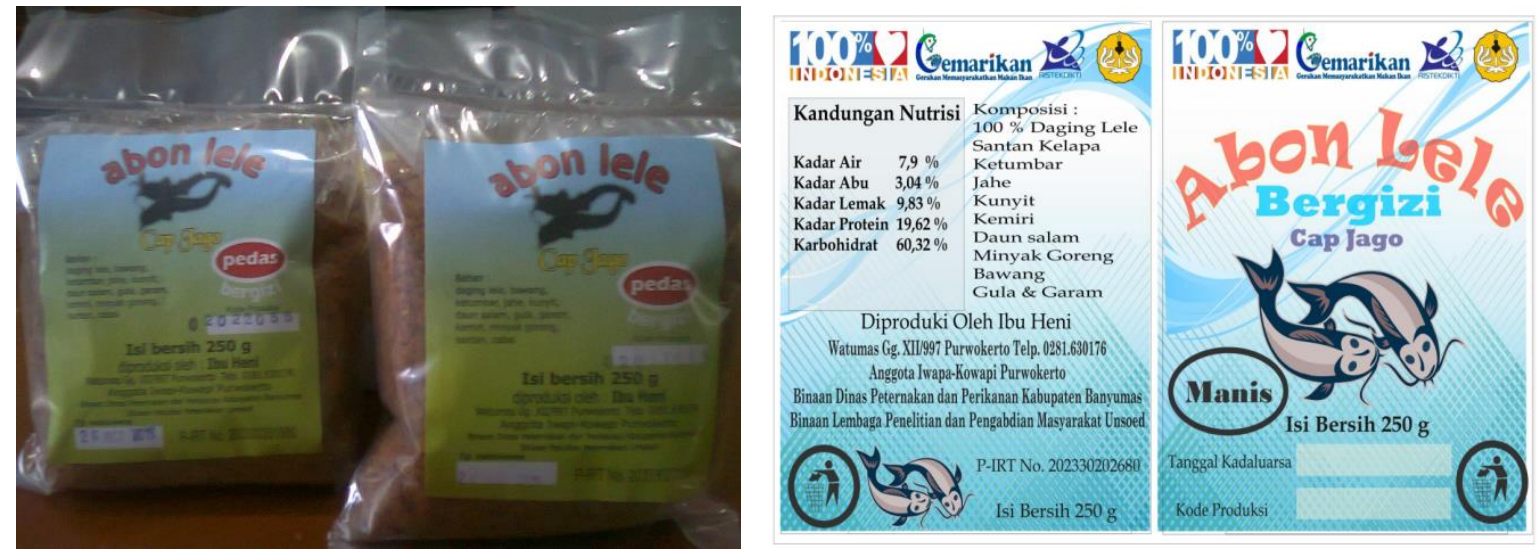


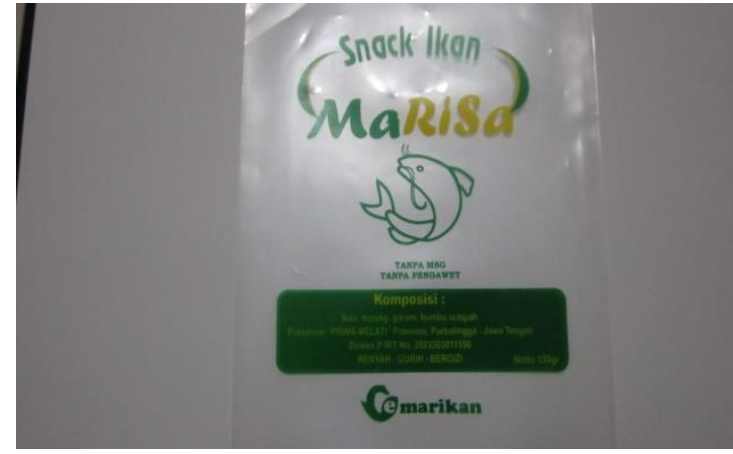

Contoh Desain Kemasan yang Lama

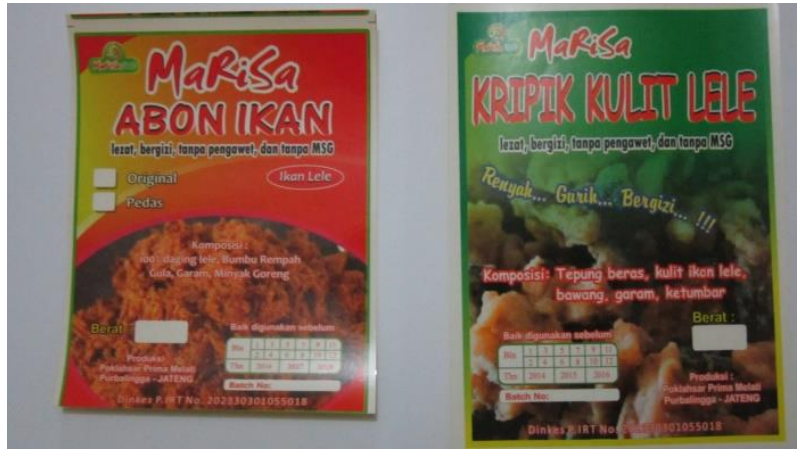

Contoh Desain Kemasan yang Baru

Gambar 2. Desain Kemasan Mitra yang Lama dan Baru

Pelatihan desain kemasan meliputi pemilihan warna, bentuk, gambar sampel, logo, dan pengisian informasi produk Desain dan pemilihan kemasan dari kegiatan ini diharapkan tidak hanya sebagai wadah pelindung produk, akan tetapi menjadi sebuah identitas atau branding produk UKM mitra di pasar.Desain kemasan juga menjadi sebuah bentuk promosi ataukomunikasi pemasaran (Junaidi dan Marhaeni, 2017) dan fungsi produk secara unik dan menarik(Muchtar dan Nurif, 2015) serta kepastian hukum labelisasi (Hasan, 2014).

Pemilihan desain dan kemasan oleh UKM mitra dalam kegiatan ini memberikan "value" tersendiri,yaitu tampilannya lebih menarik, informatif dan adanya jaminan nutrisi serta keamanan pangan serta kepercayaan konsumen akan kualitas produk.

\subsection{Analisis Kandungan Nutrisi Produk}

Analisis laboratorium penting dilakukan guna memberikan informasi dan kepercayaan kepada konsumen mengenai nilai gizi dari produk. Hasil analisis laboratorium mengenai kandungan nutrisi produk masing-masing mitra dapat dilihat pada Tabel 1.

Tabel 1. Hasil analisis laboratorium produk UKM mitra

\begin{tabular}{llccc}
\hline \multirow{2}{*}{ No } & \multirow{2}{*}{ Parameter } & Satuan & \multicolumn{2}{c}{ Produk UKM } \\
\cline { 3 - 5 } & & $\%$ & Jago & Prima Melati \\
\hline 1 & Kadar Air & $\%$ & 5,17 & 7,19 \\
2 & Kadar Abu & $\%$ & 4,74 & 3,04 \\
3 & Kadar Lemak & $\%$ & 13,28 & 9,83 \\
4 & Kadar Protein & $\%$ & 74,44 & 19,62 \\
5 & Karbohidrat & & 60,32 \\
\hline
\end{tabular}

(Sumber : Laboratorium Ilmu dan Teknologi Pangan Fakultas Pertanian Unsoed)

Kadar protein UKM mitra kegiatan ini berkisar antara $13.37 \%$ dan $19.62 \%$, dan relative lebih kecil dari UKM lain yang memproduksi abon lele yaitu sebesar $21.65 \%$ dan $24.52 \%$ seperti yang disampaikan oleh Junaidi dan Marhaeni (2017). Perbedaan kadar protein ini diduga karena metode penggorengan yang berbeda (Dewi et.al., 2011) 


\section{KESIMPULAN}

Pengetahuan dan keterampilan UKM mitra telah meningkat dalam memproduksi olahan ikan yang sehat dan mampu mendesain kemasan sebagai ciri khas produknya. Identitas produk atau brand dalam bentuk kemasan memiliki peran penting dalam daya Tarik konsumen dan penilaian kualitas produk. Rekomendasi untuk kegiatan selanjutnya, perlu dikembangkan brand awereness secara sistematik terukur dan terarah seperti pelaksanaan Good Manufacturing Product (GMP).

\section{UCAPAN TERIMA KASIH}

Penulis mengucapkan terima kasih kepada Kementrian Riset Teknologi dan Pendidikan Tinggi (Ristekdikti) atas hibah Ipteks bagi Masyarakat Tahun 2016. Penulis juga mengucapkan terima kasih kepada UKM Abon Jago dan Prima Melati atas kerjasama dan partisipasi aktifnya dalam pelaksanaan kegiatan IbM ini.

\section{DAFTAR PUSTAKA}

Dewi, E.N., R. Ibrahim., N. Yuaniva. 2011. Daya Simpan Abon Ikan Nila Merah (Oreochromis niloticus) Yang Diproses Dengan Metoda Penggorengan Berbeda. Jurnal Saintek Perikanan 6 (1) : 6-12.

Haryati, S., Aris Munandar. 2012. Penerapan Zero Waste Pada Pengolahan Abon Ikan Bandeng (Chanos chanos). Jurnal Perikanan dan Kelautan 2 (2) : 127-130

Hasan, K.N.S. 2014. Kepastian Hukum Labelisasi dan Sertifikasi Halal Produk Pangan. Jurnal Dinamika Hukum 14 (2) : 227-238.

Junaidi, T., B. Marhaeni. 2017. Labelisasi dan Sertifikasi Produk Abon Ikan Lele : Upaya Komunikasi Produsen dan Perlindungan Konsumen. Prrosiding Seminar Nasional'Pengembangan Sumber Daya Perdesaan dan Kearifan Lokal Berkelanjutan VII"17-18 November 2017 Purwokerto 819-823 p.

Kusumayanti, H. W. Astuti., R.T.D. Wisnu Broto. 2011. Inovasi Pembuatan Abon Ikan Sebagai Salah Satu Teknologi Pengawetan Ikan. Gema Teknologi 16 (3) : 119-121

Muchtar, S., Nurif, M. 2015. Peranan Packaging Dalam Meningkatkan Hasil Produksi Terhadap Konsumen. Jurnal Sosio Humaniora 8 (2) : 181-191.

Yuliana E., I. Farida. 2010. Pendekatan Partisipatif Dalam Pemecahan Aspek Produksi dan Pemasaran Abon Ikan (Studi Kasus Kelompok Usaha Bersama Tenggiri Kabupaten Sukabumi. Jurnal Organisasi dan Manajemen 6 (2) :132-145. 